\title{
The Design Path of Job Dividend Scheme for State-owned Technological Enterprises
}

\author{
Wang $\operatorname{Han}^{1 *}$, Wang $\operatorname{Dan}^{1}$, Xu Yunfei ${ }^{1}$ \\ ${ }^{1}$ State Grid Energy Research Institute Co.,Ltd., Beijing, China
}

\begin{abstract}
Job dividend is an important medium and long-term incentive method for state-owned technology enterprises. Compared with equity incentives, job dividend has the characteristics of short cycle, large coverage, and low risk. This article introduces and explains the specific implementation steps of the job dividend plan for state-owned technology enterprises. It describes in detail the formulating steps of the job dividend plan and the risks that may be encountered in the implementation process, and provides a reference for the implementation of job dividend for state-owned technology enterprises.
\end{abstract}

\section{Introduction}

Job dividends are based on the operating income of the enterprise. The method of post dividends is adopted to encourage important technical personnel and management personnel of the enterprise.

As an important medium and long-term incentive method for state-owned technology enterprises, job dividends can effectively extend the incentive cycle, thereby effectively avoiding short-term behavior of scientific researchers. In addition, the payment method of job dividends is more in line with the characteristics of long scientific research work cycle, slow conversion of results, and late results, which can more fairly measure the work results of scientific researchers from long-term benefits and allocate incentives based on this [1]. Compared with equity incentives and project income dividends, the operation of job dividends is simpler and more convenient, and the risk is relatively small. It is more suitable for state-owned technology-based enterprises that initiate medium and long-term incentives.

The feature of job dividends is that it can treat the overall business operation of the enterprise as a process of internal results transformation, and does not require explicit project results. Job dividends pay more attention to the reform dividends released by continuous innovation and process improvement for the overall operation of the company.

The advantage of post dividends is that the overall development of the company is the goal, and the incentive objects and distribution methods are linked to the posts, which is conducive to encouraging collective collaboration and inspiring employees' common vision and goals [2].

The disadvantage of job dividends is that improper operation can easily evolve into additional performance bonuses or year-end bonuses, which weaken the role of promoting technological innovation, thereby reducing fairness.k

\section{Operational steps of state-owned technology-based enterprise job dividends}

The operation of job dividends is divided into 5 steps, namely "fixed target, fixed amount, fixed distribution, fixed performance, fixed termination" [3].

TABLE I. DESIGN PATH OF JOB DIVIDEND PLAN

\begin{tabular}{|c|c|}
\hline Steps & Operation Content \\
\hline Determine the Object & $\begin{array}{l}\text { 1.Meet the policy } \\
\text { requirements } \\
\text { 2.Outstanding } \\
\text { contributions } \\
\text { important roles } \\
\text { 3.Person-post } \\
\text { matching }\end{array}$ \\
\hline Determine the Amount & $\begin{array}{l}\text { 1.Meet the dual } \\
\text { restrictions on the total } \\
\text { dividends } \\
\text { enterprises } \\
\text { individuals } \\
\text { 2.Select and } \\
\text { indicators that can } \\
\text { reflect corporate } \\
\text { profitability or value } \\
\text { creation }\end{array}$ \\
\hline $\begin{array}{l}\text { Determine } \\
\text { Allocation }\end{array}$ & $\begin{array}{l}\text { 1.Position importance } \\
\text { 2.Contribution of } \\
\text { incentive objects } \\
\text { 3.Percentage of total } \\
\text { annual dividends }\end{array}$ \\
\hline
\end{tabular}

\footnotetext{
* Corresponding author: wanghan@sgeri.sgcc.com.cn
} 


\begin{tabular}{|l|l|}
\hline Steps & \multicolumn{1}{|c|}{ Operation Content } \\
\hline Determine & $\begin{array}{l}\text { 1.Select required } \\
\text { indicators } \\
\text { Performance }\end{array}$ \\
& $\begin{array}{l}\text { 2.Determine the } \\
\text { assessment target level }\end{array}$ \\
\hline $\begin{array}{l}\text { Determine Termination } \\
\text { Conditions }\end{array}$ & $\begin{array}{l}\text { 1.Resignation or death } \\
\text { 2.Job change }\end{array}$ \\
\hline
\end{tabular}

\subsection{Determine the Incentive object}

According to relevant policy requirements, in addition to meeting the general requirements of "important technical personnel and business management personnel who have signed labor contracts with the company", the incentive objects for job dividends should also be "employed through open recruitment, internal competition or other Produced in a market-oriented way, and should have worked in this position continuously for more than one year [4]. The number of incentives each time shall not exceed $30 \%$ of the total number of employees in the enterprise."

In the selection of incentive objects, in addition to paying attention to the untouchable policy red line, it is also necessary to evaluate and screen dividend positions and incumbents. From the perspective of job selection, it is necessary to ensure that the jobs that enjoy dividend incentives are those that have outstanding contributions and important roles to the company's technological innovation, achievement transformation, and business development. Generally speaking, it is mainly based on the post sequence of operation management, scientific research management, professional technology. From the perspective of personnel selection, after determining the position sequence for dividend distribution, the company needs to analyze and evaluate the matching degree of existing personnel [5]. In addition, if the existing staff are not produced through open recruitment, internal competition for posts, or other market-oriented methods, the company also needs to carry out job recruitment and competitive recruitment to meet the policy's requirements for marketization and competitive matching of personnel and posts.

TABLE II. INCENTIVE SELECTION CONDITIONS

\begin{tabular}{|c|l|}
\hline Category & \multicolumn{1}{|c|}{ Range } \\
\hline \multirow{3}{*}{ Position } & \begin{tabular}{l} 
Position sequence of \\
operation management, \\
scientific research \\
management, \\
professional \\
technology, etc. \\
\hline 1. Meet the job \\
requirements and be \\
able to give full play to \\
its due role; \\
2.Meet the policy's \\
Techuience and \\
marketization for and \\
competitive matching \\
of job positions.
\end{tabular} \\
\hline
\end{tabular}

\subsection{Determine Incentive Amount}

According to relevant policy requirements, job dividend incentives need to meet the dual restrictions on the total amount of corporate and individual dividends. That is, "the total annual job bonus incentives of the enterprise shall not be higher than $15 \%$ of the after-tax profit of the year, and the job dividends earned by the incentive objects shall not be higher than $2 / 3$ of their total salary." $[6]$

When determining the amount of job dividend incentives, "should aim at promoting the transformation of scientific and technological achievements and improving the efficiency of business operations, adhere to the principles of incremental incentives and benefit orientation, and take into account factors such as business development strategies, self-efficiency status, and labor cost affordability. Reasonably determine the amount of bonus incentives."'[7]. Therefore, when determining the company's total job dividends, absolute indicators that can reflect the company's profitability or value creation should be selected. For example, after-tax profit, after-tax profit added value, economic added value, economic added value, etc. as the extraction base, scientifically design the accrual model and reasonably determine the extraction ratio.

\subsection{Determine the Distribution Method}

In determining the amount of dividend distribution for individual positions, the company shall, through the evaluation of the job value, sort out the importance of each position in the industrialization of scientific and technological achievements and the contribution of individual incentive targets, and use this as the basis for determining the dividend standard for each position [8]. In addition, when determining the amount of incentives, it is recommended that the proportion of the total annual dividends of the individual in the total annual salary should not be too low. In order to avoid that the per capita incentive level is too low, employees will not be able to feel the incentive, it is difficult to reflect the intensity of the incentive, and the incentive purpose cannot be achieved.

\subsection{Determine Performance Requirements}

The "Guidelines for the Implementation of Dividend Incentives for Central Technology Enterprises" clearly stipulate the performance evaluation requirements for the implementation of job dividends:

In the selection of indicators, at least one of each category should be selected among financial indicators, technological innovation indicators, and management indicators [9].

TABLE III. DIVIDEND INCENTIVE PERFORMANCE EVALUATION INDICATORS FOR STATE-OWNED TECHNOLOGY ENTERPRISES

\begin{tabular}{|c|l|}
\hline Index Category & \multicolumn{2}{|c|}{ Indicator Name } \\
\hline Finance & $\begin{array}{l}\text { Net profit growth rate } \\
\text { (required), return on net }\end{array}$ \\
\hline
\end{tabular}




\begin{tabular}{|c|l|}
\hline Index Category & \multicolumn{1}{|c|}{ Indicator Name } \\
\hline & $\begin{array}{l}\text { assets, main business } \\
\text { income growth rate, etc. }\end{array}$ \\
\hline & $\begin{array}{l}\text { Technological innovation } \\
\text { revenue growth rate, the } \\
\text { proportion of technological } \\
\text { innovation revenue to }\end{array}$ \\
operating revenue, the \\
Technology \\
Innovation \\
growth rate of new \\
(achievement \\
transformation) contract \\
value, the number of \\
patents, etc.
\end{tabular}

At the assessment target level, it is necessary to focus on the longitudinal comparison of its own historical performance levels. Encourage qualified enterprises to adopt the method of horizontal benchmarking with the performance of the same industry or benchmarking enterprises, and comprehensively determine the assessment target level. The first is to specify in the incentive plan the method of determining the evaluation target, and the selection of the method for the enterprise to target the target, and the principle of selecting the target enterprise shall be explained. The second is that the assessment target level setting should be comprehensively determined in combination with factors such as enterprise operating conditions, industry cycles, and technological development plans [10]. In principle, the relevant indicators shall not be lower than the actual performance level of the previous year or the average performance level of the company in the past three years, and the annual net profit growth index must be higher than the average growth level of the past three years. The third is to introduce industry benchmarking, the relevant indicators should not be lower than the average performance of the same industry (or the 50th quantile value of the benchmarking company).

Enterprises shall, in accordance with policy requirements and in light of the actual development of the enterprise, reasonably set performance evaluation indicators that can accurately reflect the benefits of enterprise development, technological innovation, and the orientation of enterprise development, and conform to the characteristics of enterprise operations [11]. And clarify the requirements of the assessment objectives, and give full play to the role of post dividend incentives in radiating the vitality of scientific research personnel and promoting the development of the company.

\subsection{Determine Change or Termination Conditions}

The "Guidelines for the Implementation of Dividend Incentives for Central Technology Enterprises" clearly stipulate the performance evaluation requirements for the implementation of job dividends:
The first is the resignation or death of the incentive object, that is, the incentive object himself cannot normally enjoy the job dividend incentive, then the company should determine the termination of the job dividend incentive or change the incentive amount according to the actual situation [12].

The second is that the incentive target position has changed, and the new position is not within the scope of the job dividend incentive, that is, the incentive object no longer has the qualification for the job dividend incentive. It should be agreed in advance the distribution ratio of the current year's position dividends, and the original incentive object and the new incentive object shall be distributed according to the proportion.

TABLE IV. DIVIDEND INCENTIVE PERFORMANCE EVALUATION INDICATORS FOR STATE-OWNED TECHNOLOGY ENTERPRISES

\begin{tabular}{|c|l|}
\hline Condition & \multicolumn{1}{|c|}{ Processing Method } \\
\hline $\begin{array}{c}\text { Incentive Object Leave } \\
\text { or Die }\end{array}$ & $\begin{array}{l}\text { According to the actual } \\
\text { situation, determine the } \\
\text { termination of the job } \\
\text { dividend incentive, or } \\
\text { change the incentive } \\
\text { amount. }\end{array}$ \\
\hline Incentive Target & $\begin{array}{l}\text { Arrange in advance the } \\
\text { distribution ratio of the } \\
\text { current year's position } \\
\text { dividends, and distribute } \\
\text { dividends to the original } \\
\text { incentive objects and the } \\
\text { nesitions Change }\end{array}$ \\
newcentive objects in \\
accordance with the \\
ratio.
\end{tabular}

\section{Common risks of state-owned technology-based enterprise dividends}

\subsection{Fairness of Job Dividends}

If the company's job evaluation and job competency evaluation are not perfect, it is easy to cause unfairness in the selection of incentive objects.

First, the selection of key core positions is often based on subjective impressions or completely determined according to the position level, and the core positions closely related to the development of the enterprise are not accurately selected, resulting in dissatisfaction of some positions and affecting the incentive effect.

Second, when determining the incentive targets, the analysis of the matching degree of people and posts is often ignored. In the determination of personnel, each unit usually adopts bottom-up department recommendation or top-down selection based on comprehensive performance scores. Although the methods selected are relatively good talents, they ignore some employees who are not particularly outstanding but have great potential. The final result is that the already excellent people can get extra rewards without working harder and have potential The 
potential of people is not stimulated because they are not motivated, which seriously affects the incentive effect.

\subsection{Implement "Rights Follow the Post"}

Job dividends are based on job-based dividend incentives, not based on individuals. Therefore, in the process of program design and actual implementation, the target of dividends must first be implemented in the "post". When implementing incentives and issuing dividends, the incentives are then placed on specific personnel [13].

In particular, it is necessary to pay attention to the changes in the positions of employees, the position dividend agreement must be adjusted in time according to the position adjustment situation, and it has been ensured that the final dividends are paid to those who enjoy the right to dividends.

\subsection{Motivation Scope}

According to the "Guidelines for the Implementation of Dividend Incentives for Central Technology Enterprises", the target of dividend incentives includes the following three types:

The first is technicians who play an important role in the process of technological innovation and achievement transformation. Including the main accomplishers of key scientific and technological achievements, the person in charge of major development projects, and the main technical personnel who have made major innovations or improvements to leading products or core technologies and technological processes.

The second is the senior management personnel in charge of the overall production and operation of the enterprise, and the middle and senior management personnel responsible for the production and operation of the main products (services) of the enterprise [14].

The third is the introduction of important technical talents and management talents through talent programs at the provincial, ministerial and above levels.

It can be seen that there is a high degree of overlap between the incentive objects of job dividends and the incentive objects of project income dividends, and they are mainly personnel who have made important contributions in promoting the industrialization of hightech and the transformation of scientific and technological achievements. Therefore, in choosing incentive objects for job dividends, we should also pay attention to personnel in related positions.

\section{Conclusion}

As a medium and long-term incentive method widely used by technology companies, job dividends are an important method of cash incentives. Job dividend coverage is large and the cycle is short, and it is the preferred incentive method for most technology-based enterprises to carry out medium and long-term incentives [15].

However, not all technology-based companies can implement job dividends. According to the relevant provisions of the "Interim Measures on Equity and
Dividend Incentives for State-owned Technological Enterprises", companies established for less than 3 years are not allowed to implement post dividends, and the implementation of post dividends must also meet the requirements of "the net asset appreciation formed by the accumulated after-tax profits in the past three years shall be accounted for More than $10 \%$ of the total net assets of the enterprise at the beginning of the past three years, and implement the condition that the undistributed profit at the beginning of the year is positive" [16].

The operation of job dividends is divided into 5 steps.

First, determine the object. That is, the incentive objects must meet the policy requirements, select positions with outstanding contributions and important roles, and ensure the matching of personnel and posts.

Second, determine the total dividends. The total dividends should meet the dual restrictions on the total dividends of enterprises and individuals, and an absolute indicator that can reflect the profitability or value creation of the enterprise should be selected as the basis for determining the total dividends.

Third, determine the allocation quota. Determine the specific amount of dividends based on the importance of the incentive object's position, contribution, and the proportion of the total annual dividend.

Fourth, determine performance. Performance indicators consist of two parts, the mandatory indicators specified by the policy and the individual indicators determined by the company according to its own development goals. Only when both indicators reach the target value can incentives be launched.

Fifth, determine the termination conditions. When the incentive object resigns or dies, or the position changes, the right to dividends from the position is automatically cancelled.

In addition, state-owned technology-based enterprises need to pay attention to the fairness of job dividends, implement "rights follow the post", and strictly control the scope of incentives.

\section{Acknowledgment}

This project is supported by the State Grid Corporation of China Technology Project "Research on Talent Supply and Demand Analysis Model and Supply Strategy Research Adapting to Company Strategy" (SGSC0000KXJS2000095).

\section{References}

1. Zhang, C., "Research on Equity Incentives of Nonlisted State-owned Technology Enterprises," in Human Resources Development, vol.22, Beijing, 2017, pp.193-195.

2. Wanyan, H., Hou. J., Yang. J., "Research on Incentive Management of Core Scientific Research Talents in State-owned Enterprises," in Enterprise Reform and Management, vol. 3, Beijing, 2017, pp. 103-104. 
3. Jiang, M., "Research on the Post Dividend Incentive System of Enterprise Technologists," in Economic Research Guide, vol. 9, Beijing, 2020, pp. 133-134.

4. Shi, M., "Research on the Design and Implementation of the Incentive Plan for the Dividend Right of the Enterprise Position," in China Management Information, vol. 21, Beijing, 2018, pp. 100-101.

5. Tian, M., "Analysis of the Impact of Equity Incentive Implementation," in Hebei Enterprise, vol. 4, Shijiazhuang, 2020, pp. 55-56.

6. Zhang, Z., Zhang. F., "Conventional Corporate Equity and Dividend Incentive Mechanism Design," in China Industry and Information Technology, vol.23, Beijing, 2019, pp. 90-96.

7. Yang, S., "Relevant Policies, Practices and Suggestions for State-owned Enterprises to Carry Out Equity and Dividend Incentives for Scientific and Technological Personnel," in China Human Resources Development, vol. 20, Beijing, 2020, pp. 22-29+76.

8. Yu, D., Tian, J., "The Institutional Path to Encourage Enterprise Technological Innovation with Dividend Rights," in People's Forum, vol.33, Beijing, 2013, pp. 82-84.

9. Yao, Y., "Exploring and Practicing the Reform of the Distribution System Guided by Stimulating Organizational Vitality," in The World of Labor and Social Security, vol. 3, Beijing, 2020, pp. 78-79.
10. Zhang, J., Lin. F., "Research and Design of Post Dividend Incentive Mechanism for State-owned Construction Enterprises," in China Industry and Economics, vol.4, Beijing, 2020, pp. 18-19.

11. An, W., "Research and Practice of the Implementation of Mid- and Long-term Incentives for Backbone Talents in the Institute of Military Industry," in Modern Enterprise, vol.3, Beijing, 2020, pp. $41+32$.

12. $\mathrm{Wu}, \mathrm{X}$., Chen. Y., "Accelerate the Promotion of Medium and Long-term Incentives for State-owned Science and Technology Enterprises," in Communication Enterprise Management, vol.10, Beijing, 2020, pp. 10-13.

13. Du, H., Qu. D., "Thoughts on the Implementation of Mid- and Long-term Incentive Plans by Aerospace Technology Application Industry Companies," in Satellite Applications, vol.4, Beijing, 2018, pp. 57-60.

14. Jin, Z., "Research on the Medium and Long-term Incentive Methods of State-owned Enterprise," in Modern Economic Information, vol.12, Beijing, 2017, pp. 70.

15. Yan, H., Li. Z., Luo. X., "Long-term Incentive Policies and Enlightenment of Aviation Industry," in Chinese Market, vol.29, Beijing, 2020, pp. 52-53.

16. Lin, Q., "Discussion on the Medium and Long-term Incentive Mechanism of State-owned Non-listed Enterprises," in Chinese and Foreign Entrepreneurs, vol.16, Beijing, 2019, pp. 53-55. 